have his land declared a private reserve. This will help to maintain the scenic amenities of New Zealand.

\section{The North-East Passage}

Since Baron A. E. Nordenskiöld in the Vega made the North-East Passage in 1878-79, other ships have followed the same route; but it was not until 1932 that the journey was made in one season. In that year Capt. O. J. Schmidt took the ice-breaker Siberiakov from Archangel to Vladivostok. It is now reported by Science Service that in 1934 the icebreaker Theodor Lütke, commanded by Capt. Nikolaev, went from Vladivostok to Murmansk in eightythree days. It should, however, be noted that heavy ice was encountered, and that the passage would have been impossible for a less powerful vessel. These achievements hold out little prospect for an ordinary unprotected trading vessel making use of the route for through passages.

\section{Study of Malnutrition}

A PUBLIC meeting, organised by the Committee against Malnutrition, will be held at the Conway Hall, Red Lion Square, London, W.C.1, on Thursday, May 16, at 8 p.m., to consider the health and nutrition of women and children in Great Britain. The chair will be taken by Prof. V. H. Mottram, and Miss Eleanor Rathbone, M.P., Dr. Janet Vaughan, and Prof. Marrack will be among the speakers. Tickets at $1 s$. each can be obtained from the Honorary Secretary, Mr. F. le Gros Clark, 190 Eagle Street, Holborn, W.C.1. The Committee against Malnutrition, which is a non-party organisation and has been in existence for a little more than a year, was established to obtain information respecting undernourishment among families of unemployed and lowpaid workers, and to co-ordinate efforts towards securing adequate nourishment for all. It publishes a bi-monthly bulletin, and organises propaganda on the subject. The annual subseription is $5 s$.

\section{Announcements}

THE King has been graciously pleased to command that the African Society shall henceforth be known as "The Royal African Society".

Dr. Wallace Ruddell Axkroyd has been appointed by the governing body of the Indian Research Fund Association to the post of director of nutritional research under that Association.

A meting, followed by a discussion, will be held by the British Science Guild in association with the Engineers' Study Circle on Economics, on Thursday, May 16 at 5.30 p.m. in the Lecture Theatre of the Institution of Civil Engineers, Great George Stre日t, S.W.I, when a report on schemes and proposals for economic and social reformswill be presented bylieut.Col.J.V.Delahaye. Tickets (forwhich there isnocharge) are obtainable on application to the Secretary of the British.Science Guild, 6 John Street, Adelphi, W.C.2.

The North East Coast Institution of Engineers and Shipbuilders, Newcastle-on-Tyne, will celebrate the attainment of its jubilee by a series of meetings to be held on July 16-19, in Newcastle-on-Tyne. The celebrations will open with a reception at Armstrong College. On July 17 there will be a meeting to confer honorary fellowships, after which three papers will be read dealing with developments in ship construction during the past fifty years. On July 18 papers on marine engine construction, including turbines, reciprocating steam engines, boilers and heavy oil engines, and on recent progress in electrical and general engineering, are to be read, and on the following day Sir Westcott Abell will deliver a citizens' lecture on "Ships through the Ages".

WE regret that in the article on "Canadian Water Power Developments in 1934", in our issue of April 27, p. 642, it was stated that the investment represented by the present development is estimated at 1,743,000 dollars. This should read $1,743,000,000$ dollars.

"CATtLe IN The Tropics" is the title of a booklet by Prof. Cecil Wood of the Imperial College of Tropical Agriculture, Trinidad (Government Printing Office, Port-of-Spain, 1934). It gives much useful information on the species and breeds of cattle suited to tropical conditions, their utilisation as draught animals and for meat and milk production, harnessing, feeding and general eare, breeding and improvement. Sections are also devoted to their health and the diseases which affect them, and to the organisation of the industry.

ApPLICATIONs are invited for the following appointments, on or before the dates mentioned:-A professor of physiology in University College, Dundee (University of St. Andrews)-The Secretary (May 17). A temporary assistant engineer in the Ministry of Transport-The Establishment Officer, Ministry of Transport, Whitehall Gardens, London, S.W.l (May 17). Chemists for the War Department chemist, Woolwich Arsenal-The Under-Secretary of State (C.5), The War Office, London, S.W.1 (May 18). A secretary to the Advisory Council for Technical Education in South Wales and Monmouthshire-The Advisory Council, County Hall, Cardiff (May 18). A teacher of mechanical engineering and a teacher of electrical engineering in the Schools of Technology, Art and Commerce, Oxford-The Secretary for Education, Education Office, George Street, Oxford (May 20). An animal husbandry expert under the Imperial Council of Agricultural Research, IndiaThe High Commissioner for India, General Department, India House, Aldwych, London, W.C.2 (May 25). A lecturer in mathematics in the Royal Naval College, Greenwich-The Adviser on Education, Admiralty, Whitehall, S.W.1 (May 31). An assistant professor of science in the Indian Institute of Science, Bangalore-The Director (June 1). An assistant inspector of ancient monuments for Wales -The Establishment Officer, H.M. Office of Works, Westminster, London, S.W.1 (June 3). An inspector of agriculture in the Department of Agriculture and Forests, Sudan Government-The Controller, Sudan Government London Office, Wellington House, Buck. ingham Gate, London, S.W.1 (June 10). 